\title{
PENGARUH LATIHAN TENDANGAN DEPAN DARI POSISI JONGKOK DENGAN LATIHAN MENGGUNAKAN BEBAN DI KAKI TERHADAP HASIL KECEPATAN TENDANGAN DEPAN PADA ATLET PENCAK SILAT PUTRA PERGURUAN HARIMAU HIJAIYAH LANGKAT KABUPATEN LANGKAT TAHUN 2015
}

\author{
Juli Novitasari Nasution \\ Zulfan Heri
}

\begin{abstract}
Abstrak. Penelitian ini bertujuan untuk mengetahui pengaruh latihan dari posisi jongkok dan beban dikaki terhadap hasil kecepatan tendangan depan pencak silat. Sampel yang digunkan dalam penelitian ini adalah atlet Pencak Silat Putra Perguruan Harimau Hijaiyah Langkat berjumlah 50 orang atlet dengan teknik pengambilan sampel yaitu purposive sampling. Penelitian ini menguunakan metode eksperimen dengan peberian treatment kepada para atlet selama 6 minggu dengan intensitas pertemuan 3 kali dalam seminggu. Perhitungan normalitas posisi jongkok $\mathrm{L}_{0}=0.1125<\mathrm{L}_{\text {tabel }}=0.173$, beban di kaki $\mathrm{L} 0=0.1561<\mathrm{Ltabel}=0.173$, posisi jongkok dengan usia latihan 2 tahun kebawah. L0 $=0.1512<$ Ltabel $=0.213$, beban di kaki dengan usia latihan 2 tahun kebawah $\mathrm{L} 0=0.1562<\mathrm{Ltabel}=0.213$, posisi jongkok dengan usia latihan 2 tahun keatas L0 $=0.2390<\mathrm{Ltabel}=0.271$, beban di kaki dengan usia latihan 2 tahun keatas $L 0=0.2583<$ Ltabel $=0.271$ yang keseluhan uji menyatakan data normal.

Hasil pengujian hipotesis diperoleh hasil yaitu

a. tidak terdapat pengaruh latihan tendangan dari posisi jongkok dengan latihan menggunakan beban di kaki terhadap hasil kecepatan tendangan pada atlet putra Perguruan Pencak Silat Harimau Hijaiyah Berdasarkan hasil perhitungan $\mathrm{F}_{\text {hitung }}=0.02$ dan $\mathrm{F}_{\text {tabel }}=4.05$, sehingga $\mathrm{F}_{\text {hitung }}<\mathrm{F}_{\text {tabel }}$

b. terdapat pengaruh hasil kecepatan tendangan depan pada atlet dengan usia latihan dua tahun kebawah dengan atlet usia latihan dua tahun keatas pada atlet pencak silat putra Perguruan Harimau Hijaiyah Berdasarkan hasil perhitungan $\mathrm{F}_{\text {hitung }}=32.13$ dan $\mathrm{F}_{\text {tabel }}=4.05$, sehingga $\mathrm{F}_{\text {hitung }}>\mathrm{F}_{\text {tabel }}$

c. tidak terdapat pengaruh antara latihan tendangan depan posisi jongkok dan latihan tendangan depan menggunakan beban di kaki serta umur latihan terhadap hasil kecepatan tendangan depan pada atlet pencak silat putra Perguruan Harimau Hijaiyah Berdasarkan hasil perhitungan $\mathrm{F}_{\text {hitung }}=0.04$ dan $\mathrm{F}_{\text {tabel }}=4.04$, sehingga $\mathrm{F}_{\text {hitung }}<$ Ftabel
\end{abstract}

Kata Kunci : Tendangan Depan, Posisi Jongkok, Beban Di Kaki, Kecepatan, Pencak Silat

\section{PENDAHULUAN}

Pencak silat merupakan cabang olahraga asli Indonesia. Iskandar (1992:23) mengungkapkan: "Pencak silat adalah beladiri tradisional Indonesia yang berakar dari budaya Melayu, dan bisa ditemukan hampir di wilayah seluruh Indonesia. Setiap daerah memiliki kekhasan ciri gerakanya sendiri-sendiri". Teknik dalam pencak silat sangat beragam. Setiap aliran atau perguruan memiliki teknik yang berbeda satu sama lain. Secara umum teknik dasar adalah pukulan, tendangan, tangkisan atau hindaran, jatuhan dan kuncian. Dan setiap teknik tersebut masih terbagi-bagi lagi jenisnya.

Pencak silat merupakan olahraga yang yang sering mengharumkan nama Indonesia di event-event tertentu, seperti Kejuaraan Dunia Pencak Silat Tahun 2015 yang dilaksanakan di Thailand. Indonesia berhasil meraih juara umum. Untuk menjadi seorang atlet pencak silat, penampilan seorang pesilat yang bermutu, dituntut untuk menguasai berbagai teknik dasar yang memegang peranan penting, seperti yang dikemukakan Iskandar (1992:69) a). Langkah dan pola langkah. b). Sikap pasang pengembangannya. c). Teknik elakan. d). 
Teknik serangan. e). Teknik jatuhan dan. f). Teknik kuncian, juga didukung dengan fisik serta taktik dan mental yang baik.

Pada bulan Oktober sampai

Desember 2014, peneliti melakukan observasi dan wawancara dengan pelatih di Perguruan Pencak Silat Harimau Hijaiyah Langkat (Harihilang) Kabupaten Langkat yang bernama Irwansyah S.Pd dan Rusliadi. Berdasarkan pernyataan pelatih, mereka melakukan latihan selama 3 kali dalam seminggu, yaitu pada hari Selasa, Kamis, Sabtu. Jumlah atlet yang berlatih di perguruan tersebut sebanyak 60 orang atlet putra dan putri yang tergabung dalam beberapa kelas dan kategori. Beberapa orang atlet telah berlatih selama 1 sampai 2 tahun, bahkan sampai 4 tahun (terlampir). Antusias atlet berlatih cukup baik.

Namun pelatih hanya membuat satu program latihan untuk keseluruhan atlet, tidak membedakan intensitas latihannya, baik untuk yang latihan dengan lama 1 tahun maupun yang berlatih selama 4 tahun bahkan untuk putra maupun putri tidak ada perbedaan. Dengan atlet yang cukup banyak, pelatih juga cukup kesulitan mengontrol atlet, sehingga terkadang atlet tidak terpantau dengan baik.

Dengan latihan seperti di atas pelatih mengatakan terdapat cukup banyak kekurangan dalam latihan. Mereka telah cukup baik dalam latihan teknik karena pelatih dapat memberikan latihan dengan materi yang sama secara bersamaan. Namun dalam latihan fisik mereka memiliki cukup banyak kekurangan. Seperti latihan tendangan dan pukulan yang tidak cepat, sehingga dapat mudah untuk ditangkis dan ditangkap oleh lawan, tendangan dan pukulan yang dilakukan tidak memiliki power yang baik hanya menempel pada body protector, saat melakukan tendangan, pukulan dan tangkapan tidak memiliki momentum yang tepat, tidak dapat menyelesaikan tangkapan hingga menjadi jatuhan karena tidak adanya kekuatan otot lengan.

Dari beberapa faktor penentu prestasi tersebut, faktor fisik merupakan salah satu faktor penting dan mutlak untuk dikembangkan secara optimal pada diri setiap atlet, termasuk atlet pencak silat.
Karena tanpa kondisi fisik yang prima sulit bagi atlet untuk berprestasi secara maksimal. Dalam pengembangan kondisi fisik atlet pencak silat belum banyak pilihan metode latihan yang digunakan, khususnya dalam pengembangan kecepatan yang diperlukan.

Pelatih di daerah dalam penyusunan program latihannya pada umumnya masih didasarkan pada pengalaman semata pada saat menjadi atlet, belum sampai pada tahapan mencari tahu informasi apa yang tepat untuk metode latihan yang sesuai dengan kondisi atletnya. Selain itu pembinaan olahraga prestasi di daerah terkesan berjalan sangat lamban, bahkan cenderung tak berkembang, karena belum diterapkan pengembangan olahraga melalui pendekatan ilmiah. Hal ini dapat dilihat dari sarana dan prasarana yang ada di pada daerahnya, yang pada umumnya masih sangat kurang. Hal yang sama terjadi juga dalam pembinaan atlet pencak silat di Kabupaten Langkat.

Dalam olahraga pencak silat, teknik yang dominan dipakai adalah tendangan. Tendangan merupakan serangan yang paling sering dipakai pada saat pertandingan oleh atlet pencak silat khususnya pesilat dari Perguruan Harimau Hijaiyah Langkat Kabupaten Langkat. Tendangan merupakan salah satu teknik yang banyak meraih keuntungan bila dibandingkan teknik pukulan. Tendangan akan menghasilkan peluang yang lebih besar untuk menciptakan poin dalam setiap pertandingan. Tendangan yang sering digunakan dalam latihan dan pertandingan adalah tendangan depan. Dibandingkan dengan tendangan sabit tendangan depan cukup sulit untuk ditangkap dan ditangkis oleh lawan.

Berdasarkan uraian diatas, maka penulis tertarik untuk melakukan penelitian yang berjudul "Pengaruh Latihan Tendangan Depan dari Posisi Jongkok dengan Latihan Menggunakan Beban di Kaki Terhadap Hasil Kecepatan Tendangan Depan Pada Atlet Pencak Silat Putra Perguruan Harimau Hijaiyah Langkat Kabupaten Langkat Tahun 2015". 


\section{KERANGKA TEORI PENCAK SILAT}

Pencak silat merupakan olahraga beladiri yang telah berkembang hampir diseluruh dunia. Di Indonesia sendiri, pencak silat berkembang dengan pesat dan melahirkan atlet-atlet yang berprestasi. Kemudian perkembangannya sendiri di dunia sudah cukup merata. Ini dibuktikan pada saat kejuaraan Pencak Silat Dunia yang berlangsung pada tahun 2015 di Thailand. Banyak pemenang pertandingan didominasi oleh negara lain selain Indonesia. Ini merupakan suatu kebanggaaan buat Indonesia, karena pencak silat adalah olahraga beladiri khas Indonesia yang terus berkembang dan disambut baik oleh negara lain.

Menurut Iskandar, dkk. (1992: 22) mengemukakan bahwa:

"Pencak silat adalah gerak dasar bela diri yang terikat pada peraturan dan digunakan dalam belajar berlatih dan pertunjukan. Beladiri yang sempurna bersumber pada kerohanian yang suci murni, guna keselamatan diri untuk kesejahteraan bersama .menghindarkan diri dari bala atau bencana, perampok, penyakit dan segala sesuatu yang jahat atau merugikan masyarakat".

"Sedangkan menurut Pengurus Besar IPSI bersama BAKIN pada tahun 1975(dalam Iskandar, dkk 1992:11) pencak silat adalah "Hasil budaya Indonesia untuk membela/mempertahankan eksistensi (kemandirian) dan integritasnya (manunggalnya) terhadap lingkungan hidup/alam sekitarnya untuk mencapai keselarasan hidup guna peningkatan iman dan taqwa kepada Tuhan Yang Maha Esa".

Dalam olahraga pencak silat memiliki beberapa kategori yang dipertandingkan antara lain, kategori tanding dan seni yang biasanya di sebut TGR (Tunggal, Ganda, dan Regu).

$$
\text { "Johansyah Lubis (2003:7) }
$$

mengemukakan bahwa "Katagori tanding adalah kategori yang menampilkan dua pesilat dari kubu yang berbeda. Keduanya saling berhadapan menggunakan unsur pembelaan dan serangan, yaitu menangkis/mengelak/mengena menyerang pada sasaran dan menjatuhkan lawan, penggunaan taktik dan teknik bertanding, ketahanan stamina dan semangat juang, menggunakan kaidah dan pola langkah yang memanfaatkan kekayaan teknik jurus, untuk mendapatkan nilai terbanyak".

\section{TENDANGAN DEPAN}

Seperti yang dikatakan oleh Johansyah Lubis (2004:13): "Jenis tendangan dalam pencak silat bermacammacam diantaranya, tendangan lurus, tendangan sabit, tendangan sisi/T, tendangan jejak dan tendangan belakang".

Dalam olahraga pencak silat tendangan sama pentingnya dengan teknik pukulan dan teknik yang lainnya, namun tendangan lebih cenderung menguntungkan, karena mempunyai nilai yang lebih tinggi, kekuatan yang lebih besar dan jangkauan yang lebih panjang. Dalam suatu pertandingan, teknik serangan berupa tendangan yang memiliki nilai 2 (dua).

Tendangan yang dimaksud peneliti adalah teknik tendangan depan. Menurut Johansyah Lubis (2003:26) yaitu: "Tendangan depan atau tendangan lurus adalah serangan yang menggunakan sebelah kaki dan tungkai, lintasannya ke arah depan dengan posisi badan menghadap ke depan, dengan kenaannya pangkal jari-jari kaki bagian dalam, dengan sasaran ulu hati”.

Dalam pelaksanaan tendangan lurus bagian tubuh yang dominan dipergunakan adalah tungkai kaki, pinggang dan posisi badan. Adapun tahapan dalam melakukan tendangan lurus meliputi:

1. Mengangkat paha ke depan sejajar dengan pinggul. Lutut dalam keadaan bengkok sehingga terjadi anteflexi pada tungkai atas dan retroflexi pada tungkai bawah. Otot yang berkontraksi pada gerakan ini adalah otot-otot paha bagian depan sebagai penggerak utama yaitu; musculus illiopsoas, rectus femoris, sartorius, tensor fascia latae, glutaei medius dan musculus adductores.

2. Meluruskan tungkai bawah ke depan dengan jari-jari kaki ditekuk ke atas. Gerakan ini menyebabkan terjadinya eksistensi antara tungkai atas dan tungkai bawah. Otot yang berfungsi pada gerakan ini adalah otot-otot paha bagian belakang yaitu; musculus biceps 
femoris, soleus, flexor hallucis longus, tuibialis posterior, pronaci longus, extensor digitorum longus, dan extensor hallucis longus. Dari segi mekanika gerakan, sendi lutut (articulatio knee) merupakan sumbu gerakan. Tenaga yang diperoleh dari gerakan tersebut diteruskan ke tulang tibia dan fibula (os scuris) sebagai force (lengan gaya). Bagian kaki yang mengenai sasaran adalah ujung telapak kaki.

3. Menarik kembali kaki penendang sambil mengambil posisi untuk mengantisipasi serangan lawan. Sebenarnya, gerakan tendangan lurus ke depan sudah selesai dengan berakhirnya gerakan meluruskan tungkai ke depan dengan ujung kaki yang telah ditekuk, tetapi kaki penendang perlu ditarik dengan cepatan setelah melakukan tendangan agar dapat mengambil posisi siap siaga untuk menangkis atau mengelakkan serangan lawan, serta untuk mengambil posisi untuk menyerang kembali.

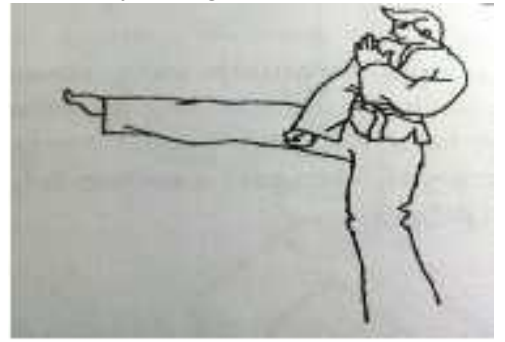

Gambar 1. Tendangan Depan atau Tendangan Lurus

Johansyah Lubis (2004)

Keuntungan dan kekurangan dari tendangan depan yaitu tendangan mendapatkan posisi istimewa dalam pencaksilat tendangan depan sering digunakan untuk memulai ataupun mendahului serangan lawan, lebih mudah mengenai sasaran, karena lintasannya lurus ke depan dan perkenaannya pada ujung telapak kaki.

Kelemahan dari tendangan ini adalah jika gerak balikan tidak cepat maka sangat mudah tendangan tersebut untuk ditangkap. Kondisi fisik sangat memberi dukungan terhadap kecepatan tendangan depan, sehingga harus dilatih dan dikembangkan secara maksimal. Tujuannya adalah agar diperoleh hasil tendangan yang benar-benar optimal dan efektif.

\section{KECEPATAN TENDANGAN}

Pada saat melakukan tendangan depan atau tendangan lurus dalam pertandingan pencak silat diperlukan kecepatan agar tendangan tidak ditangkap ataupun ditangkis oleh lawan. Dalam pertandingan olahraga pencak silat tendangan sangat diperlukan dalam mengumpulkan poin.

Menurut Nugroho, 2005:17 (dalam Aqil Azizi, 2013) mengatakan: "Dari ketiga teknik dasar yaitu pukulan, tedangan dan tangkapan yang dapat digunakan untuk memperoleh point, kira-kira $47 \%$ yang paling dominan digunakan dalam pertandingan adalah teknik tendangan”. Tendangan mempunyai beberapa keuntungan antara lain tendangan mendapatkan nilai yang cukup tinggi yaitu dua poin. Jangkauannya lebih panjang serta mempunyai power yang lebih besar dibanding dengan serangan lain yaitu pukulan hanya memperoleh nilai satu. Berdasarkan penelitian Erwin, 2010 (dalam Aqil Azizi, 2013) "Teknik tendangan memiliki presentase yang cukup besar untuk memperoleh poin. Sebesar 45\% tendangan depan menghasilkan poin. Berarti dapat dikatakan tendangan tersebut berhasil masuk pada sasaran tanpa tertangkis serta bertenaga". Oleh sebab itu kecepatan sangat diperlukan dalam latihan maupun pertandingan, selain kecepatan kondisi fisik juga harus mendukung.

Bompa \& Haff (2009:315) dan dalam Syafruddin (2011:26) mengatakan yaitu: "Kecepatan adalah kemampuan untuk menyelesaikan suatu jarak tertentu dengan cepat. Dapat disimpulkan kecepatan merupakan kualitan kondisional yang memungkinkan seseorang olahragawan untuk bereaksi secara cepat bila dirangsang dan untuk menampilkan/melakukan gerakan secepat mungkin".

Ada 6 faktor yang mempengaruhi kecepatan menurut Harsono (1998:218) yaitu:

1. Keturunan (heredity) dan natural talent

2. Waktu reaksi 
3. Kemampuan untuk mengatasi tahanan (resistance) eksternal seperti peralatan, lingkungan, dan lawan

4. Teknik, misalnya gerakan lengan, tungkai, sikap tubuh pada waktu lari

5. Konsentrasi dan semangat

6. Elastisitas otot

Menurut Syafruddin (2011:87)

bahwa: "Kecepatan sangat tergantung dari kekuatan (langsung) karena tanpa kekuatan, kecepatan tidak dapat dikembangkan. Jika seseorang atlet ingin mengembangkan kecepatan maksimalnya maka ia juga harus mengembangkan kekuatannya.

Latihan kekuatan memerlukan intensitas beban luar yang tinggi. Jika intensitas beban luar tinggi maka kecepatan gerakan tidak dapat berkembang. Sebaliknya, jika intensitas beban luar rendah maka kekuatan tidak akan berkembang, karena otot tidak tertantang mengatasi beban yang rendah. Kekuatan otot dapat berkembang jika diberi beban latihan dengan intensitas tinggi. Dengan kata lain, jika ingin meningkatkan kekuatan otot dengan menggunakan beban luar selain beban tubuh sendiri, maka intensitas beban latihannya harus tinggi. Kemudian jika ingin meningkan kecepatan gerakan menggunakan beban luar, maka intensitas beban latihannya harus rendah.

Dapat disimpulkan bahwa kecepatan tendangan yaitu merupakan gerakan/kemampuan untuk melakukan tendangan dengan cepat, kuat dan akurat serta tepat pada sasaran. Maka untuk mencapai hasil kecepatan tendangan depan atau tendangan lurus dengan baik dapat digunakan bentuk latihan tendangan depan dari posisi jongkok dan latihan tendangan depan menggunakan beban di kaki.

\section{LATIHAN}

Menurut Bompa (1994:2) "Latihan adalah aktivitas cabang olahraga yang dilakukan secara sistematis dalam waktu yang lama dan ditingkatkan secara progressive dan individual yang mengarah kepada ciri-ciri fisiologis dan psikologis untuk mencapai sasaran yang telah ditentukan".
Faktor-faktor latihan tersebut meliputi latihan fisik, teknik, taktik, dan psikis. Untuk itu proses latihan tersebut selalu bercirikan antara lain:

a. Suatu proses untuk mencapai tingkat kemampuan yang lebih baik dalam berolahraga yang memerlukan waktu tertentu (tahapan) serta perencanaan yang cermat.

b. Proses latihan harus teratur dan bersifat progresif.

c. Pada setiap kali tatap muka (satu sesi latihan) harus memiliki tujuan dan sasaran.

d. Materi latihan harus berisikan materi teori dan praktik, agar pemahaman dan penguasaan keterampilan menjadi relatif permanen

e. Menggunakan metode tertentu, yaitu cara paling efektif yang direncanakan secara bertahap dengan memperhitungkan faktor kesulitan, kompleksitas gerak dan penekanan pada sasaran latihan.

\section{INTENSITAS LATIHAN}

Setiap kegiatan fisik yang ditampilkan atlet, akan mengarah kepada suatu perubahan anatomis, fisiologis, biokimia, dan kejiwaannya. Efisiensi dari suatu kegiatan merupakan akibat dari waktu yang dipakai, jarak yang ditempuh dan jumlah ulangan atau volume, beban dan kecepatan atau intensitas, serta frekuensi penampilan atau densitas.

Semua komponen tersebut harus dipertimbangkan dan dirancang sedemikian rupa oleh pelatih untuk meningkatkan kemampuan seorang atlet dalam peningkatan prestasi. Dan dalam penyusunan program latihan, pelatih harus melihat komponen mana yang lebih dibutuhkan dalam cabang olahraga tersebut. Sebagai aturan yang sudah umum, olahraga yang membutuhkan kecepatan dan daya eksplosif, penekannya terletak pada intensitasnya, sedangkan daya tahan terletak pada volumenya.

Intensitas latihan sangat dibutuhkan dalam program latihan. Intensitas adalah fungsi dari kekuatan rangsang syaraf yang dilakukan dalam latihan. Kuatnya rangsangan tergantung dari beban kecepatan gerakannya, variasi interval atau 
istirahat di antara ulangannya. Elemen yang tidak kalah pentingnya adalah tekanan kejiwaan sewaktu latihan. Jadi intensitas tidak semata-mata diukur dari usaha yang dilakukan otot saja, tetapi juga pengeluaran tenaga pada syaraf selama melakukan latihan atau pertandingan

Intensitas pada setiap cabang olahraga berbeda satu dengan yang lainnya. Tingkat intensitas dapat diukur sesuai dengan jenis latihannya. Untuk latihan yang melibatkan kecepatan, diukur dalam meter perdetik tentang rata-rata gerakan yang dilakukan untuk setiap menitnya. Intensitas kegiatan yang dilakukan untuk melawan tahanan, dapat diukur dalam $\mathrm{kg}$ atau $\mathrm{kgm}$ (1 $\mathrm{kg}$ diangkat setinggi $1 \mathrm{~m}$ melawan gaya berat). Ada beberapa cara untuk mengukur besarnya rangsangan terhadap kekuatan dan intensitasnya. Sebagai contoh, latihan melawan tahanan atau bentuk latihan yang akan mengembangkan kecepatannya, adalah dengan melalui prosentase dari intensitas maksimalnya, dimana 100\% merupakan intensitas tertinggi

Pada penelitian ini digunakan intensitas maksimal yang mengacu pada pembagian tingkat intensitas berdasarkan denyut nadi yang dikemukakan oleh Nossek dan Joseph.

Tabel 1. Tingkat Intensitas Latihan dengan Denyut Nadi

\begin{tabular}{|l|l|l|}
\hline Angka \% & $\begin{array}{l}\text { Prestasi } \\
\text { Terbaik }\end{array}$ & $\begin{array}{l}\text { Kualitas } \\
\text { Intensitas } \\
\text { Denyut Nadi }\end{array}$ \\
\hline $30-50 \%$ & Rendah & $130-140$ \\
$50-60 \%$ & Mudah & $140-150$ \\
$60-75 \%$ & Sedang & $150-165$ \\
$75-85 \%$ & Sub & $165-180$ \\
$85-100 \%$ & Maksimal & 180 ke atas \\
& Maksimal & \\
\hline
\end{tabular}

(Sumber: Nossek, Joseph. 1982. General Theory of Training.

Lagos. Pan African Ltd:27)

Selama berlatih si atlet dipaksa untuk merasakan berbagai tingkatan intensitas. Organisme menyesuaikan fungsi fisiologinya untuk memenuhi tuntutan latihan. Berdasarkan atas perubahan fisiologis ini khususnya denyut jantung
(Heart Rate), pelatih harus mendeteksi serta memantau intensitas program latihannya. Untuk mengembangkan kemampuan biomotorik, intensitas rangsangan harus mencapai atau melebihi ambang rangsang (trheshold) dimana pengaruh latihan secara nyata berada

Untuk meningkatkan kemampuan fisik harus berupa gerakan tubuh yang terencana, terstruktur dan repetitive (berulang) utuk memperbaiki atau memulihkan satu atau lebih komponen fisik. (Halliwell and Whiteman,2004). Pada komponen kondisi fisik kecepatan, meruapakan latihan anaerobik. Pada latihan dengan intensitas latihan rendah, mudah dan sedang biasanya merupakan latihan yang dapat dilakukan secara kontinu dalam waktu yang cukup lama. Sedangkan latihan dengan intensitas latihan submaksimal dan maksimal merupakan latihan dengan intensitas yang tinggi tidak dapat dilakukan secara kontinu dalam waktu yang lama.

Dengan memperhatikan prinsipprinsip latihan kecepatan tersebut kemudian perlu disusun suatu program latihan yang sistematis, agar latihan dapat meningkatkan kekuatan secara efektif. Permasalahan yang menjadi dasar latihan kecepatan yang sistematis antara lain adalah jumlah berat beban, jumlah ulangan (repetisi) dan jumlah rangkaian dari suatu masa latihan per hari, serta beberapa kali setiap minggu latihan dilakukan. Para ahli dalam mengembangkan dan mencari program latihan yang efektif biasanya melakukan berbagai manipulasi terhadap keempat masalah pokok tersebut, ditambah dengan waktu pemulihan atau waktu istirahat antara satu rangkaian berikutnya.

\section{PRINSIP-PRINSIP LATIHAN}

Prinsip latihan banyak dikemukakan oleh para pakar, yaitu : Tudor O Bompa dan G. Gregory Haff (2009), Brent S. Rushall dan Frank S. Payke (1990), Frank S. Payke (1991), Manfred Letzelter (1978). Kemudian menurut Syafruddin (2011:162) prinsip-prinsip latihan yang lebih penting untuk dibahas dan dipahami oleh pelaku pembinaan olahraga terutama pelatih dan atlet berdasarkan rangkuman dari para pakar. 


\section{a. Prinsip Superkompensasi}

Berasal dari kata "super" yaitu di atas atau merasa lebih dan "kompensasi" yaitu penggantian. Superkompensasi berarti penggantian yang lebih atau melebihi.

\section{b. Prinsip Beban Lebih}

Prinsip beban lebih (overload principle) atau prinsip peningkatan beban secara progresif merupakan salah satu prinsip latihan yang paling populer dalam pembinaan prestasi olahraga. Prinsip ini lebih menekankan pada peningkatan beban latihan yang diberikan kepada atlet berdasarkan kemampuan atlet pada saat latihan. Semakin tinggi tingkat kemampuan atlet maka semakin berat atau semakin intensif beban latihan yang diberikan, atau dengan kata lain semakin berat latihan yang dilakukan. Penurunan beban latihan atau beban latihan yang konstan (tetap) dalam waktu cukup dan terus menerus dapat mengakibatkan terjadinya suatu penurunan kemampuan (prestasi) secara pelan-pelan.

Seperti apa yang dikemukakan oleh Bompa dalam Harsono (1988:105) menyarankan apa yang disebut "the step type apporoach atau sistem tangga. Berikut dapat kita lihat skema dari penambahan beban secara bertahap menurut Harsono :

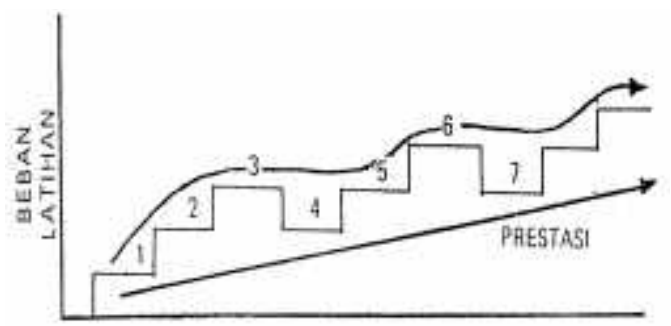

Gambar 2. Penambahan Beban Secara Bertahap

Harsono (1988 : 108)

\section{c. Prinsip Variasi Beban}

Untuk meraih prestasi puncak yang diharapkan membutuhkan waktu yang cukup lama. Sehingga masa-masa latihan bagi atlet sering kali menjemukan atau membosankan. Untuk mengatasi kejemuan dan kebosanan dalam berlatih, pelatih perlu menggunakan metode-metode dan materi latihan secara bervariasi. Di samping itu, variasi juga bisa dilakukan dalam mengatur dan mendosis beban latihan, seperti pengaturan istirahat pemulihan (recovery) dalam metode interval dengan memperpanjang atau memperpendek waktu pemulihan sesuai dengan tujuan latihan.

\section{d. Prinsip Periodisasi dan Prinsip Kontinuitas Beban}

Periodisasi dalam suatu proses pembinaan olahraga dapat diartikan sebagai pentahapan proses pembinaan dalam rentang waktu satu tahun program pembinaan. Periodisasi atau pentahapan tersebut dapat juga diartikan dengan fase atau masa seperti fase persiapan, masa kompetisi, masa transisi dan lain sebagainya. Setiap periode atau masa dalam suatu perencanaan tahunan memiliki tujuan dan sasaran tertentu sesuai dengan kebutuhan dan karakteristik cabang olahraganya. Proses latihan harus berlangsung secara teratur atau dengan kata lain tidak boleh terputus dalam waktu yang lama.

Beban latihan ditingkatkan secara lambat dan tetap sehingga dapat mempertahankan prestasi yang telah dicapai dalam waktu yang lama. Prestasi yang diraih terlalu cepat tidak dapat bertahan lama atau cepat pula menurunnya (Rothing \& Grossing, 1985:70).

\section{e. Prinsip Individualisasi}

Proses pembinaan dan latihan olahraga adalah proses yang berhubungan dengan manusia atau individu manusia. Setiap manusia memiliki sifat dan karakter yang berbeda-beda. Perbedaan ini menuntut para pelatih untuk dapat memahami sifat dan karakter atletnya agar latihan yang diberikan bisa lebih terarah sesuai dengan tujuan yang diharapkan.

\section{f. Prinsip Spesialisasi}

Prinsip spesialisasi lebih menekankan kepada prinsip spesifikasi cabang olahraga. Hal ini disebabkan setiap cabang olahraga mempunyai ciri-ciri tersendiri dan itulah yang membedakan tuntutan dan kebutuhan tiap cabang olahraga, baik kebutuhan kondisi fisik, teknik maupun terhadap kebutuhan taktik dan mental. Spesialisasi menurut Bompa \& Haff (2009:35) merupakan proses yang kompleks yang didasari oleh perkembangan secara multilateral (menyeluruh). Sesuai dengan yang dikemukakan oleh Pete (1984:318) bahwa 


\section{TENDANGAN DEPAN DARI POSISI JONGKOK}

Peneliti menggunakan latihan tendangan depan dari posisi jongkok untuk melatih kecepatan. Kecepatan merupakan pembawaan sejak lahir (genetika), sehingga komponen kecepatan memiliki keterbatasan yaitu tergantung pada struktur otot dan mobilitas proses-proses syaraf. Sebagai akibatnya, peningkatan kecepatan juga relatif terbatas yaitu antara 20-30\%. Menurut Josef Nossek (1982:62) "Gerakangerakan kecepatan dilakukan dengan melawan tahanan yang berbeda (berat badan, berat peralatan, air)".

(Dikutip dari: Jurnal Olahraga Prestasi, Volume 3, Nomor 1, Januari 2007)

Berdasarkan wawancara dengan pelatih pencak silat yaitu Rusliadi, Irwansyah, S.Pd dan atlet nasional yaitu Pedomanta Keliat S,Pd, bahwa latihan dari posisi jongkok kemudian berdiri melakukan tendangan dapat meningkatkan kecepatan tendangan atlet. Karena saat proses melakukan tendangan atlet memiliki beban dari tubuh sendiri dan dibantu dengan menggunakan beban atau bending yang dipasang di kaki atlet. Sehingga saat melakukan tendangan apabila dilakukan dengan cepat, dapat meningkatkan kecepatan tendangan.

Berdasarkan pendapat dari para ahli di atas, bahwa tendagan depan dari posisi jongkok dapat meningkatkan kecepatan tendangan depan. Adapun cara melakukan latihan tendangan depan dari posisi jongkok, yaitu:

1. Ambil poisisi jongkok.

2. Kemudian berdiri dengan satu kaki, dan kaki yang lain menendang diangkat setinggi lutut.

3. Lakukan tendangan depan atau tendangan lurus sasaran ulu hati dengan benar,

4. Selesai menendang lipat kembali dan ambil posisi jongkok.

5. Lakukan berkali-kali dengan kaki yang bergantian.

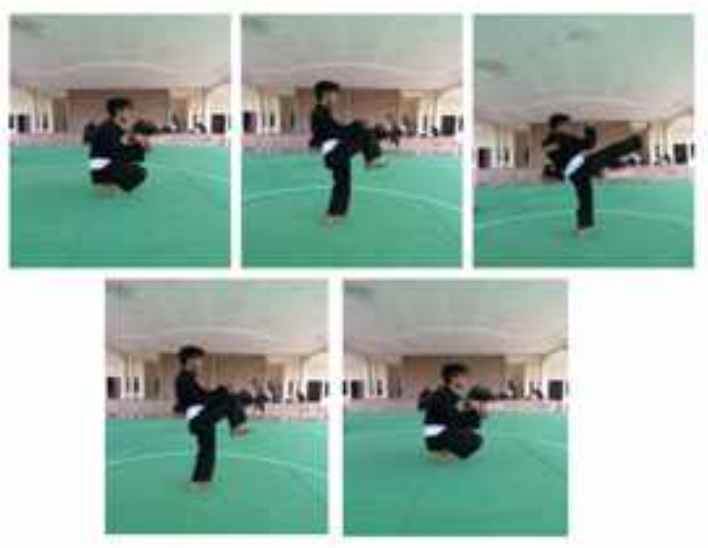

Gambar 3. Tendangan Depan dari Posisi Jongkok

(Sumber: Dokumentasi Penulis)

\section{TENDANGAN \\ DEPAN \\ MENGGUNAKAN BEBAN DI KAKI}

Bending atau ankle weight adalah alat pemberat kaki yang terbuat dari kain yang diberikan pemberat dengan serbuk besi. Salah satu bentuk latihan ankle weight yakni ankle weight diikatkan pada daerah kaki atau diatas ankle kaki.

Bending sering dipergunakan atlet untuk melatih kecepatan juga untuk latihan kekuatan, khususnya pada cabang olahraga beladiri. Latihan dengan pemberat di kaki dapat digunakan untuk memperoleh kecepatan gerak yang maksimal. Sebagaimana yang dikatakan oleh Syafruddin (2011:87) bahwa:

"Kecepatan sangat tergantung dari kekuatan (langsung) karena tanpa kekuatan, kecepatan tidak dapat dikembangkan. Jika seseorang atlet ingin mengembangkan kecepatan maksimalnya maka ia juga harus mengembangkan kekuatannya. Hal ini disebabkan kemampuan kecepatan yang diperoleh sangat tergantung dari impuls (dorongan) kekuatan dan merupakan produk dari massa tubuh dan kecepatan tubuh itu sendiri. Sehingga terdapat korelasi negatif antara kekuatan dan kecepatan dalam mengatasi beban luar (contoh beban barbel atau dambell).

Dari pernyataan beberapa ahli di atas, dapat disimpulkan bahwa latihan mengguanakan pemberat kaki atau bending dapat sangat berpengaruh terhadap hasil 
kecepatan tendangan depan. Adapun cara pelaksanaannya adalah:

1. Pemberat kaki atau bending diikatkan pada kedua pergelangan kaki.

2. Ambil posisi kuda-kuda depan, yakni kuda-kuda dengan sikap salah satu kaki berada di depan, sedangkan kaki lainnya berada dibelakang.

3. Lakukan tendangan depan atau tendangan lurus.

4. Lakukan untuk kanan dan kiri.

5. Setelah menendang kembali ke posisi semula seperti ingin menendang.

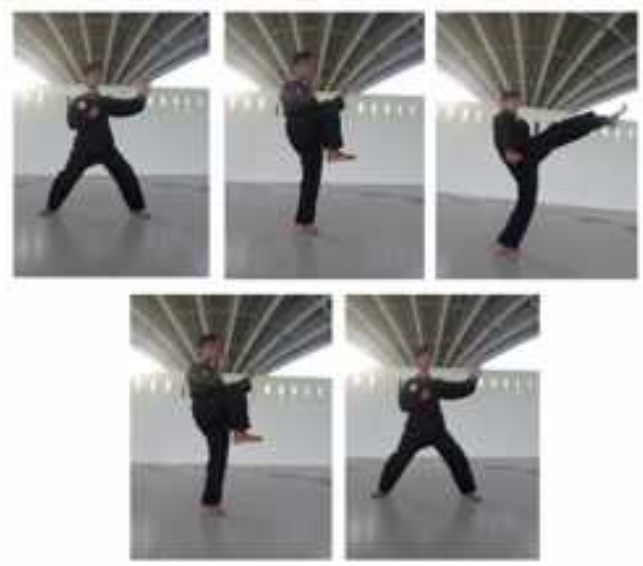

Gambar 4. Tendangan Depan

Menggunakan Beban di Kaki

(Sumber: Dokumentasi Penulis)

\section{KERANGKA BERPIKIR}

Olahraga pencak silat adalah olahraga beladiri yang dilakukan dengan tangan kosong (gerakan-gerakan) yang dilakukan terdiri dari gerakan anggotaanggota tubuh seperti gerakan tangan, gerakan kaki dan gerakan tubuh lainya. Oleh sebab itu diperlukan otot-otot pergerakan yang kuat juga cepat dan semua ini bisa terjadi jika kekuatan, fleksibilitas dan kecepatan reaksi sudah dilatih.

Kemampuan dalam melakukan tendangan depan ini perlu dilatih dengan baik, karena dengan latihan yang baik dan tepat serta efisien dapat meningkatkan kecepatan tendangan. Tendangan yang cepat dan akurat akan susah untuk di tangkap oleh lawan dan dapat menghasilkan poin yang bersih. Terdapat banyak variasi latihan yang dapat meningkatkan kecepatan tendangan depan, diantaranya adalah melakukan latihan tendangan depan dari posisi jongkok dan latihan tendangan depan menggunakan beban di kaki.

Perbedaan kecepatan tendangan menggunakan beban dari posisi jongkok dengan latihan tendangan depan menggunakan beban di kaki, berdasarkan pendapat para ahli diatas bahwa apabila beban yang berat dan porsi latihan yang sesuai dapat meningkatkan hasil kecepatan tendangan. Latihan tendangan depan dari posisi jongkok menggunakan beban diri sendiri dan beban dumbell yang diikatkan pada kaki bagian bawah. Sedangkan tendangan depan menggunakan beban di kaki hanya menggunakan beban yang ada di kaki bagian bawah.

Peneliti tidak hanya membedakan berdasarkan bentuk latihan namun peneliti ingin melihat apakah terdapat perbedaan hasil kecepatan tendangan berdasarkan umur latihan atlet. Pendapat para ahli mengatakan bahwa bila umur latihan semakin lama maka peningkatan akan semakin sulit dilakukan karena perkembangannya sudah hampir maksimal.

Setiap latihan yang dilakukan dengan sungguh-sungguh dengan tidak mengabaikan prinsip-prinsip latihan akan dapat membina dan membentuk keterampilan yang optimal. Begitu juga halnya pada latihan tendangan depan dari posisi jongkok dengan latihan tendangan depan menggunakan beban di kaki dilakukan secara berulang-ulang, akan memberikan respon fisiologis yang positif kepada otot tungkai dan akan beradaptasi untuk menerima beban yang diberikan. Dengan demikian otot tungkai akan semakin kuat dan cepat, sehingga tendangan depan akan semakin meningkat kecepatannya.

Dengan adanya pernyataan diatas, diharapkan dengan memberikan latihan tendangan depan dari posisi jongkok dengan latihan tendangan depan dengan menggunakan beban di kaki akan dapat diketahui bahwa kedua latihan tersebut berpengaruh terhadap hasil kecepatan tendangan depan. Dan pernyataan ini akan dibuktikan melalui penelitian yang akan 
dilakukan pada atlet putera pencak silat Harimau Hijaiyah Langkat Kabupaten Langkat Tahun 2015.

\section{METODE PENELITIAN}

Metode yang digunakan dalam penelitian ini adalah metode eksperimen dengan desain faktorial $2 \times 2$. Dalam penelitian ini terdapat tiga variabel penelitian, yaitu satu variabel terikat dan dua variabel bebas. Sebagai variabel terikat (dependent variabel) hasil kecepatan tendangan (Y) dan dua variabel bebas (independent variabel) latihan tendangan dari posisi jongkok dengan latihan tendangan depan menggunakan beban di kaki.

Variabel perlakuan metode latihan beban (A) dibedakan menjadi dua, yaitu latihan tendangan depan dari posisi jongkok (A1) dan latihan tendangan depan menggunakan tendangan beban di kaki (A2). Variabel atribut (B) dibedakan menjadi dua kelompok, yaitu umur latihan dua tahun keatas (B1) dan umur latihan dua tahun kebawah (B2). Adapun matrik rancangan faktorial $2 \times 2$ adalah :

Tabel 2. Rancangan Faktorial 2x2

\begin{tabular}{|l|l|l|}
\hline $\begin{array}{l}\text { Bentuk } \\
\text { Latihan }\end{array}$ & $\begin{array}{l}\text { Latihan } \\
\text { Tendangan } \\
\text { dari Posisi }\end{array}$ & $\begin{array}{l}\text { Latihan } \\
\text { Tendangan } \\
\text { Menggunakan } \\
\text { Uatihan } \\
\text { Leban di Kaki } \\
\text { (A1) }\end{array}$ \\
\hline $\begin{array}{l}\text { Dua } \\
\text { tahun } \\
\text { kebawah } \\
\text { (B1) }\end{array}$ & A1B1 & A2B1 \\
\hline $\begin{array}{l}\text { Dua } \\
\text { tahun } \\
\text { keatas } \\
\text { (B2) }\end{array}$ & A1B2 & A2B2 \\
\hline
\end{tabular}

Keterangan

A1B1 = Kelompok latihan tendangan dari posisi jongkok bagi atlet yang memiliki umur latihan dua tahun kebawah

A2B1 = Kelompok latihan tendangan depan menggunakan beban di kaki bagi atlet yang memiliki umur latihan dua tahun kebawah

A1B2 = Kelompok latihan tendangan dari posisi jongkok bagi atlet yang memiliki umur latihan dua tahun keatas
A2B2 = Kelompok latihan tendangan depan menggunakan beban di kaki bagi atlet yang memiliki umur latihan dua tahun keatas

\section{DESAIN PENELITIAN}

Sehubungan dengan hal tersebut maka peneliti menggunakan metode yang dianggap sesuai dengan permasalahan yang hendak diteliti yaitu menggunakan metode eksperimen, dengan rancangan penelitian yang sesuai dengan permasalahan yakni menggunakan rancangan pre-test dan posttest one group design, untuk dapat dilihat pada tabel berikut :

Tabel 3. Bentuk Desain Penelitian Pre-Test dan Post-Test

\begin{tabular}{|c|c|c|}
\hline $\begin{array}{l}\text { Pre- } \\
\text { Test (T1) }\end{array}$ & Treatment & $\begin{array}{l}\text { Post- } \\
\text { Test } \\
\text { (T-2) }\end{array}$ \\
\hline $\begin{array}{l}\text { Test hasil } \\
\text { Kecepatan } \\
\text { Tendangan } \\
\text { Depan }\end{array}$ & $\begin{array}{l}\text { Di bagi } \\
\text { menggunakan } \\
\text { Matching by } \\
\text { Pairing } \\
\text { Latihan } \\
\text { tendangan depan } \\
\text { dari posisi } \\
\text { jongkok dan } \\
\text { Latihan } \\
\text { tendangan depan } \\
\text { memakai } \\
\text { pemberat di kaki }\end{array}$ & $\begin{array}{l}\text { Tes } \\
\text { hasil } \\
\text { Kecepa } \\
\text { tan } \\
\text { Tendan } \\
\text { gan } \\
\text { Depan }\end{array}$ \\
\hline
\end{tabular}

\section{HASIL PENELITIAN}

Berdasarkan hasil penelitian yang dilakukan, yaitu tes dan pengukuran tendangan terhadap 50 orang sampel. Dari semua sampel akan dilihat pengaruh latihan tendang depan dari posisi jongkok dengan latihan tendangan menggunakan beban di kaki pada atlet Pencak Silat Putra Perguruan Harimau Hijaiyah Langkat Kabupaten Langkat Tahun 2015.

Terlebih dahulu sampel melakukan pre-test untuk mengetahui kemampuan awal atlet dalam mengikuti latihan. Kemudian melakukan latihan tendangan depan dari posisi jongkok dengan latihan tendangan menggunakan beban di kaki selama 6 minggu (3 kali seminggu). Untuk mengetahui apakah terdapat pengaruh dari 
bentuk latihan tersebut, maka setelah waktu latihan dilakukan tes akhir (post-test). Hasil tes dan pengukuran dideskripsikan sebagai berikut:

Tabel 7. Hasil Pre-Test Kecepatan Tendangan Depan Kelompok Umur Latihan Dua Tahun Kebawah (Latihan Tendangan Depan dari Posisi Jongkok)

\begin{tabular}{|c|c|}
\hline Nilai Statistik & $\mathbf{X}$ \\
\hline Jumlah Data & 16 \\
\hline $\begin{array}{c}\text { Hasil Tendangan } \\
\text { Terendah }\end{array}$ & 13 \\
\hline $\begin{array}{c}\text { Hasil Tendangan } \\
\text { Tertinggi }\end{array}$ & 17 \\
\hline Rata-Rata & 14.81 \\
\hline Simpangan Baku & 1.22 \\
\hline
\end{tabular}

Dari hasil pre-test latihan tendangan depan dari posisi jongkok dengan umur latihan dua tahun kebawah terhadap peningkatan hasil kecepatan tendangan depan pada atlet pencak silat putra Harimau Hijaiyah Langkat Kabupaten Langkat Tahun 2015, diperoleh data hasil kecepatan tendangan dengan rentang jumlah antara 13 - 17 nilai rata-rata 14,81 , simpangan baku 1,22.

Tabel 8. Hasil Post-Test Kecepatan Tendangan Depan Kelompok Umur Latihan Dua Tahun Kebawah (Latihan Tendangan Depan dari Posisi Jongkok)

\begin{tabular}{|c|c|}
\hline Nilai Statistik & X \\
\hline Jumlah Data & 16 \\
\hline $\begin{array}{c}\text { Hasil Tendangan } \\
\text { Terendah }\end{array}$ & 15 \\
\hline $\begin{array}{c}\text { Hasil Tendangan } \\
\text { Tertinggi }\end{array}$ & 19 \\
\hline Rata-Rata & 17.06 \\
\hline Simpangan Baku & 1.18 \\
\hline
\end{tabular}

Dari hasil post-test latihan tendangan depan dari posisi jongkok dengan umur latihan dua tahun kebawah terhadap peningkatan hasil kecepatan tendangan depan pada atlet pencak silat putra Harimau Hijaiyah Langkat Kabupaten Langkat Tahun 2015, diperoleh data hasil kecepatan tendangan dengan rentang jumlah antara 15-19 nilai rata-rata 17,06.
Tabel 9. Hasil Pre-Test Kecepatan Tendangan Depan Kelompok Umur Latihan Dua Tahun Kebawah (Latihan Tendangan Depan Menggunakan Beban di Kaki)

\begin{tabular}{|c|c|}
\hline Nilai Statistik & $\mathbf{X}$ \\
\hline Jumlah Data & 16 \\
\hline $\begin{array}{c}\text { Hasil Tendangan } \\
\text { Terendah }\end{array}$ & 15 \\
\hline $\begin{array}{c}\text { Hasil Tendangan } \\
\text { Tertinggi }\end{array}$ & 18 \\
\hline Rata-Rata & 14.81 \\
\hline Simpangan Baku & 1.05 \\
\hline
\end{tabular}

Dari hasil pre-test latihan tendangan depan menggunakan beban di kaki dengan umur latihan dua tahun kebawah terhadap peningkatan hasil kecepatan tendangan depan pada atlet pencak silat putra Harimau Hijaiyah Langkat Kabupaten Langkat Tahun 2015, diperoleh data hasil kecepatan tendangan dengan rentang jumlah antara 15-18 nilai rata-rata 14,81 .

Tabel 10. Hasil Post-Test Kecepatan Tendangan Depan Kelompok Umur Latihan Dua Tahun Kebawah (Latihan Tendangan Depan Menggunakan Beban di Kaki)

\begin{tabular}{|c|c|}
\hline Nilai Statistik & $\mathbf{X}$ \\
\hline Jumlah Data & 16 \\
\hline $\begin{array}{c}\text { Hasil Tendangan } \\
\text { Terendah }\end{array}$ & 15 \\
\hline $\begin{array}{c}\text { Hasil Tendangan } \\
\text { Tertinggi }\end{array}$ & 18 \\
\hline Rata-Rata & 17.06 \\
\hline Simpangan Baku & 1.00 \\
\hline Standar Deviasi & 1.00 \\
\hline
\end{tabular}

Dari hasil post-test latihan tendangan depan menggunakan beban di kaki dengan umur latihan dua tahun kebawah terhadap peningkatan hasil kecepatan tendangan depan pada atlet pencak silat putra Harimau Hijaiyah Langkat Kabupaten Langkat Tahun 2015, diperoleh data hasil kecepatan tendangan dengan rentang jumlah antara 15-18 nilai rata-rata 17,06 . 
Tabel 11. Hasil Pre-Test Hasil Kecepatan Tendangan Depan Kelompok Umur Latihan Dua Tahun Keatas (Latihan Tendangan Depan dari Posisi Jongkok)

\begin{tabular}{|c|c|}
\hline Nilai Statistik & $\mathbf{X}$ \\
\hline Jumlah Data & 9 \\
\hline $\begin{array}{c}\text { Hasil Tendangan } \\
\text { Terendah }\end{array}$ & 17 \\
\hline $\begin{array}{c}\text { Hasil Tendangan } \\
\text { Tertinggi }\end{array}$ & 20 \\
\hline Rata-Rata & 17.33 \\
\hline Simpangan Baku & 0.87 \\
\hline
\end{tabular}

Dari hasil pre-test latihan tendangan depan dari posisi jongkok dengan umur latihan dua tahun keatas terhadap peningkatan hasil kecepatan tendangan depan pada atlet pencak silat putra Harimau Hijaiyah Langkat Kabupaten Langkat Tahun 2015, diperoleh data hasil kecepatan tendangan dengan rentang jumlah antara 17 - 20 nilai rata-rata 17,33

Tabel 12. Hasil Post-Test Kecepatan Tendangan Depan Kelompok Umur Latihan Dua Tahun Keatas (Latihan Tendangan Depan dari Posisi Jongkok)

\begin{tabular}{|l|l|}
\hline Nilai Statistik & $\mathbf{X}$ \\
\hline Jumlah Data & 9 \\
\hline $\begin{array}{l}\text { Hasil Tendangan } \\
\text { Terendah }\end{array}$ & 17 \\
\hline $\begin{array}{l}\text { Hasil Tendangan } \\
\text { Tertinggi }\end{array}$ & 20 \\
\hline Rata-Rata & 18.67 \\
\hline Simpangan Baku & 0.87 \\
\hline Standar Deviasi & 0.75 \\
\hline
\end{tabular}

Dari hasil post-test latihan tendangan depan dari posisi jongkok dengan umur latihan dua tahun keatas terhadap peningkatan hasil kecepatan tendangan depan pada atlet pencak silat putra Harimau Hijaiyah Langkat Kabupaten Langkat Tahun 2015, diperoleh data hasil kecepatan tendangan dengan rentang jumlah antara 17-20 nilai rata-rata 18,67.
Tabel 13. Hasil Pre-Test Kecepatan Tendangan Depan Kelompok Umur Latihan Dua Tahun Keatas (Latihan Tendangan Depan Menggunakan Baban di Kaki)

\begin{tabular}{|c|c|}
\hline Nilai Statistik & X \\
\hline Jumlah Data & 9 \\
\hline $\begin{array}{c}\text { Hasil Tendangan } \\
\text { Terendah }\end{array}$ & 18 \\
\hline $\begin{array}{c}\text { Hasil Tendangan } \\
\text { Tertinggi }\end{array}$ & 20 \\
\hline Rata-Rata & 17.56 \\
\hline Simpangan Baku & 1.01 \\
\hline
\end{tabular}

Dari hasil pre-test latihan tendangan depan menggunakan beban di kaki dengan umur latihan dua tahun keatas terhadap peningkatan hasil kecepatan tendangan depan pada atlet pencak silat putra Harimau Hijaiyah Langkat Kabupaten Langkat Tahun 2015, diperoleh data hasil kecepatan tendangan dengan rentang jumlah antara 18 - 20 nilai rata-rata 17,56.

Tabel 14. Hasil Post-Test Kecepatan Tendangan Depan Kelompok Umur Latihan Dua Tahun Keatas (Latihan Tendangan Depan Menggunakan Baban di Kaki)

\begin{tabular}{|c|c|}
\hline Nilai Statistik & $\mathbf{X}$ \\
\hline Jumlah Data & 9 \\
\hline $\begin{array}{c}\text { Hasil Tendangan } \\
\text { Terendah }\end{array}$ & 18 \\
\hline $\begin{array}{c}\text { Hasil Tendangan } \\
\text { Tertinggi }\end{array}$ & 20 \\
\hline Rata-Rata & 18.78 \\
\hline Simpangan Baku & 0.67 \\
\hline Standar Deviasi & 0.44 \\
\hline
\end{tabular}

Dari hasil post-test latihan tendangan depan dari posisi jongkok dengan umur latihan dua tahun keatas terhadap peningkatan hasil kecepatan tendangan depan pada atlet pencak silat putra Harimau Hijaiyah Langkat Kabupaten Langkat Tahun 2015, diperoleh data hasil kecepatan tendangan dengan rentang jumlah antara 18-20 nilai rata-rata 18,78. 


\section{PENGUJIAN} ANALISA

\section{PERSYARATAN}

\section{Uji Normalitas}

a. Perhitungan normalitas hasil kecepatan tendangan kelompok latihan tendangan depan dari posisi jongkok secara keseluruhan. Dari hasil perhitungan pada table di atas diperoleh $\mathrm{L}_{0}=0.1125$. Pada taraf $\alpha=0.05$ diperoleh $\mathrm{L}_{\text {tabel }}=0.173$. Dengan demikian $\mathrm{L}_{0}=0.1125<\mathrm{L}_{\text {tabel }}=$ 0.173, berarti $\mathrm{H}_{0}$ diterima. Kesimpulannya adalah sampel berasal dari populasi yang berdistribusi Normal.

b. Perhitungan normalitas hasil kecepatan tendangan kelompok latihan tendangan depan menggunakan beban di kaki secara keseluruhan Dari hasil perhitungan pada table di atas diperoleh L0 $=0.1561$. Pada taraf $\alpha=0.05$ diperoleh Ltabel $=0.173$. Dengan demikian $\mathrm{L0}=0.1561<$ Ltabel $=0.173$, berarti H0 diterima. Kesimpulannya adalah sampel berasal dari populasi yang berdistribusi Normal.

c. Perhitungan normalitas hasil kecepatan tendangan depan kelompok latihan tendangan depan dari posisi jongkok dengan usia latihan 2 tahun kebawah. Dari hasil perhitungan pada table di atas diperoleh L0 $=0.1512$. Pada taraf $\alpha=$ 0.05 diperoleh Ltabel $=0.213$. Dengan demikian L0 $=0.1512<$ Ltabel $=0.213$, berarti H0 diterima. Kesimpulannya adalah sampel berasal dari populasi yang berdistribusi Normal.

d. Perhitungan normalitas hasil kecepatan tendangan depan kelompok latihan tendangan depan menggunakan beban di kaki dengan usia latihan 2 tahun kebawah. Dari hasil perhitungan pada table di atas diperoleh $\mathrm{L} 0=0.1562$. Pada taraf $\alpha=0.05$ diperoleh Ltabel $=0.213$. Dengan demikian L0 $=0.1562<$ Ltabel $=0.213$, berarti $\mathrm{HO}$ diterima. Kesimpulannya adalah sampel berasal dari populasi yang berdistribusi Normal.

e. Perhitungan normalitas hasil kecepatan tendangan depan kelompok latihan tendangan depan dari posisi jongkok dengan usia latihan 2 tahun keatas. Dari hasil perhitungan pada table di atas diperoleh L0 $=0.2390$. Pada taraf $\alpha=$
0.05 diperoleh Ltabel $=0.271$. Dengan demikian L0 $=0.2390<$ Ltabel $=0.271$, berarti H0 diterima. Kesimpulannya adalah sampel berasal dari populasi yang berdistribusi Normal.

f. Perhitungan normalitas hasil kecepatan tendangan depan kelompok latihan tendangan depan menggunakan beban di kaki dengan usia latihan 2 tahun keatas. Dari hasil perhitungan pada table di atas diperoleh L0 $=0.2583$. Pada taraf $\alpha=$ 0.05 diperoleh Ltabel $=0.271$. Dengan demikian $\mathrm{L} 0=0.2583<\mathrm{Ltabel}=0.271$, berarti H0 diterima. Kesimpulannya adalah sampel berasal dari populasi yang berdistribusi Normal.

\section{Uji Homogenitas}

Uji Homogenitas untuk ke empat kelompok perlakuan menggunakan Uji Bartlett

Tabel 15. Data Perlakuan Uji Homogenitas

\begin{tabular}{|l|l|l|l|l|}
\hline \multirow{2}{*}{ Statistik } & \multicolumn{4}{|l|}{ Kelompok Perlakuan } \\
\cline { 2 - 5 } & Kel 1 & Kel 2 & Kel 3 & Kel 4 \\
\hline Rata-Rata & 17.06 & 17.06 & 18.67 & 18.78 \\
\hline $\begin{array}{l}\text { S. } \\
\text { Deviasi }\end{array}$ & 1.18 & 1.00 & 0.87 & 0.67 \\
\hline Varians & 1.40 & 1.00 & 0.75 & 0.44 \\
\hline $\begin{array}{l}\text { Jumlah } \\
\text { data (n) }\end{array}$ & 16 & 16 & 9 & 9 \\
\hline
\end{tabular}

\section{PENGUJIAN HIPOTESIS}

1. Pengujian Hipotesis I

Dari hasil pengujian hipotesis pertama yaitu, terdapat pengaruh hasil kecepatan tendangan depan dengan latihan tendangan depan dari posisi jongkok dengan tendangan depan menggunakan beban di kaki pada atlet pencak silat putra Perguruan Harimau Hijaiyah Langkat Kabupaten Langkat Tahun 2015. Berdasarkan hasil perhitungan $\mathrm{F}_{\text {hitung }}=0.02$ dan $F_{\text {tabel }}=4.05$, sehingga $F_{\text {hitung }}<\mathrm{F}_{\text {tabel }}$ maka dapat disimpulkan bahwa tidak terdapat pengaruh hasil kecepatan tendangan depan.

Berdasarkan kriteria pengujian hipotesis yaitu Ho diterima dan Ha ditolak, maka dalam penelitian ini menyimpulkan bahwa "tidak terdapat pengaruh latihan tendangan dari posisi jongkok dengan 
latihan menggunakan beban di kaki terhadap hasil kecepatan tendangan pada atlet putra Perguruan Pencak Silat Harimau Hijaiyah Langkat Kabupaten Langkat Tahun 2015".

\section{Pengujian Hipotesis II}

Dari hasil pengujian hipotesis kedua yaitu, terdapat pengaruh hasil kecepatan tendangan depan pada atlet dengan usia latihan dua tahun kebawah dengan atlet usia latihan dua tahun keatas pada atlet pencak silat putra Perguruan Harimau Hijaiyah Langkat Kabupaten Langkat Tahun 2015. Berdasarkan hasil perhitungan $\mathrm{F}_{\text {hitung }}=32.13$ dan $\mathrm{F}_{\text {tabel }}=4.05$, sehingga $F_{\text {hitung }}>F_{\text {tabel }}$ maka dapat disimpulkan bahwa terdapat pengaruh pada hasil kecepatan tendangan.

Berdasarkan kriteria pengujian hipotesis yaitu Ho ditolak dan Ha diterima. Maka dalam penelitian ini menyimpulkan bahwa "terdapat pengaruh hasil kecepatan tendangan depan pada atlet dengan usia latihan dua tahun kebawah dengan atlet usia latihan dua tahun keatas pada atlet pencak silat putra Perguruan Harimau Hijaiyah Langkat Kabupaten Langkat Tahun 2015”.

\section{Pengujian Hipotesis III}

Dari hasil pengujian hipotesis pertama yaitu, terdapat pengaruh antara latihan tendangan depan posisi jongkok dan latihan tendangan depan menggunakan beban di kaki serta umur latihan terhadap hasil kecepatan tendangan depan pada atlet pencak silat putra Perguruan Harimau Hijaiyah Langkat Kabupaten Langkat Tahun 2015. Berdasarkan hasil perhitungan $\mathrm{F}_{\text {hitung }}=0.04$ dan $\mathrm{F}_{\text {tabel }}=4.04$, sehingga $\mathrm{F}_{\text {hitung }}<$ Ftabel maka dapat disimpulkan bahwa tidak berpengaruh.

Berdasarkan kriteria pengujian hipotesis yaitu Ho diterima dan Ha ditolak, maka dalam penelitian ini menyimpulkan bahwa "tidak terdapat pengaruh antara latihan tendangan depan posisi jongkok dan latihan tendangan depan menggunakan beban di kaki serta umur latihan terhadap hasil kecepatan tendangan depan pada atlet pencak silat putra Perguruan Harimau Hijaiyah Langkat Kabupaten Langkat Tahun 2015".

\section{PEMBAHASAN HASIL PENELITIAN}

Hasil pengujian hipotesis pertama menunjukkan bahwa tidak terdapat pengaruh latihan tendangan dari posisi jongkok dengan latihan menggunakan beban di kaki terhadap hasil kecepatan tendangan pada atlet putra Perguruan Pencak Silat Harimau Hijaiyah Langkat Kabupaten Langkat Tahun 2015. Dengan lama latihan 3 kali dalam seminggu dalam waktu 6 minggu dapat meningkatkan hasil kecepatan tendangan depan. Ini disebabkan bahwa atlet yang tidak disiplin dalam menghadiri latihan, kemudian dengan jumlah atlet yang banyak, sehingga latihan tidak dapat di kontrol dengan baik oleh pelatih. Sehingga banyak atlet yang bermain saat melakukan latihan.

Hasil pengujian hipotesis kedua menunjukkan bahwa terdapat pengaruh hasil kecepatan tendangan depan pada atlet dengan usia latihan dua tahun kebawah dengan atlet usia latihan dua tahun keatas pada atlet pencak silat putra Perguruan Harimau Hijaiyah Langkat Kabupaten Langkat Tahun 2015". Saat melakukan latihan tendangan depan dari posisi jongkok dengan latihan menggunakan beban di kaki merupakan bentuk latihan yang cukup sering dilakukan namun belum terprogram dengan baik. Dengan peneliti menerapkan kembali kedua bentuk latihan tersebut membuat semangat atlet menjadi bangkit. Terutama pada atlet yang umur latihannya dua tahun keatas merasa senang dengan bentuk latihan tersebut, sehingga berusaha mengikuti program dengan baik. Namun pada kelompok umur latihan dua tahun kebawah merasa cepat bosan dengan bentuk latihan yang tidak bervariasi, sehingga meraka kurang antusias dalam mengikuti program.

Hasil pengujian hipotesis ketiga diketahui bahwa tidak terdapat pengaruh antara latihan tendangan depan posisi jongkok dan latihan tendangan depan menggunakan beban di kaki serta umur latihan terhadap hasil kecepatan tendangan depan pada atlet pencak silat putra Perguruan Harimau Hijaiyah Langkat Kabupaten Langkat Tahun 2015. Mungkin faktor terbesar adalah pengawasan saat 
melakukan latihan, sehingga atlet akan melakukan latihan dengan sungguhsungguh dan didukung dengan sarana dan prasarana yang memadai untuk lebih berprestasi.

\section{KESIMPULAN}

Dari hasil pengujian hipotesis ditarik kesimpulan sebagai berikut :

1. tidak terdapat pengaruh latihan tendangan dari posisi jongkok dengan latihan menggunakan beban di kaki terhadap hasil kecepatan tendangan pada atlet putra Perguruan Pencak Silat Harimau Hijaiyah Langkat Kabupaten Langkat Tahun 2015

2. terdapat pengaruh hasil kecepatan tendangan depan pada atlet dengan usia latihan dua tahun kebawah dengan atlet usia latihan dua tahun keatas pada atlet pencak silat putra Perguruan Harimau Hijaiyah Langkat Kabupaten Langkat Tahun 2015

3. tidak terdapat pengaruh antara latihan tendangan depan posisi jongkok dan latihan tendangan depan menggunakan beban di kaki serta umur latihan terhadap hasil kecepatan tendangan depan pada atlet pencak silat putra Perguruan Harimau Hijaiyah Langkat Kabupaten Langkat Tahun 2015

\section{SARAN}

Sesuai kesimpulan yang diperoleh dari penelitian yang membandingkan dua bentuk latihan dan umur latihan, maka dikemukakan beberapa saran untuk meningkatkan hasil kecepatan tendangan pada atlet pencak silat khususnya di Sumatera Utara, yaitu:

1. Kepada pelatih dan guru agar memperhatikan bentuk latihan, program latihan yang sesuai untuk peningkatan tujuan yang ingin dicapai dalam peningkatan prestasi.

2. Kepada para atlet diharapkan lebih berkonsentrasi dan fokus dalam menjalankan program latihan yang telah diberikan oleh pelatih.

3. Kepada para pembaca, disarankan untuk melakukan penelitian lanjutan dalam pengembangan untuk meningkatkan fisik, teknik dan taktik dalam pencak silat.

\section{DAFTAR PUSTAKA}

Arikunto, Suharsimi.2010. Prosedur Penelitian, Suatu Pendekatan Praktik. Jakarta: PT. Rineka Cipta.

Irianto, Agus.1988.Statistik Pendidikan (1). Jakarta: Departemen Pendidikan dan Kebudayaan Direktorat Jenderal Pendidikan Tinggi Proyek Pengembangan Lembaga Pendidikan Tenaga Kependidikan.

Iskandar, dkk.1992. Pencak Silat. Jakarta:

Departemen Pendidikan dan

Kebudayaan Proyek

Pengembangan Lembaga

Pendidikan Tenaga Kependidikan.

Lubis, Johansyah.2004. Pencak Silat Panduan Praktis. Jakarta: PT. Rajagrafindo Persada. 2004 .

Instrumen Pemanduan Bakat. Direktorat Olahraga Pelajar dan Mahasiswa, Direktorat Jenderal Olahraga Pendidikan Nasional.

Muhlisin. Pengaruh Latihan Bench Press dan Berat Badan Terhadap Hasil Tolak Peluru Gaya O'Briaen pada Peserta Didik Putra Kelas II SMK Negeri 1 Wanareja Kabupaten Cilacap Tahun Pelajaran 2006/2007. Semarang:UNNES.

Suryadi, V.Yoyok.2002. Taekwondo, Pomse Tae Jeuk. Jakarta: PT. Gramedia Pustaka Utama.

Syafruddin.2011. Ilmu Kepelatihan Olahraga. Padang: UNS Press Padang.

Tarigan, Fredy.2013. Kontribusi Latihan Maegeri dari Posisi Jongkok dan Variasi Kelentukan Otot Pinggang Terhadap Peningkatan Kecepatan Maegeri Chudan pada Atlet Karateka Putra Perguruan Kei Shin Kai Medan. Unimed. 